\title{
KOMUNIKASI MASYARAKAT JEPANG DITINJAU DARI SISI MANAJEMEN PRIVASI KOMUNIKASI (Studi Kasus Pada Mahasiswa Graduate University For Advance Studies)
}

\section{Vera Eka Krisnawati}

\begin{abstract}
The aim of the article is to describe communication characteristic of Japanese who identified has cautious behaviour relating to their interaction with foreigners. This study is trying to observe and explore it by using Communication Private Management theory. By appliying qualitative method this study focus on specific subject, students of Graduate University for Advanced Studies in Sagamihara, Japan. The result of the study show that the interaction between Japanese and foreigners run well as long as they have similar self perception. Japanese people would be very generous and kind as long as the communication is clear.
\end{abstract}

Keywords: Communication Private Management theory (CPM), Japan, Japanese People.

\section{Pendahuluan}

Penelitian ini dimulai dengan observasi bahwa hampir semua penelitian mengenai budaya Jepang menyatakan bahwa masyarakat Jepang merupakan salah satu ras dengan etnisitas paling eksklusif. Penelitian sebelumnya mengakui adanya etnisitas tersebut dengan membandingkan etnisitas yang berasal dari ras yang berbeda. Pada umumnya, masyarakat dunia mengenal tiga macam ras yang ada, yaitu ras Mongoloid, ras Negroid, dan ras Kaukasoid. Namun beberapa lagi mengakui adanya ras ke empat yaitu ras Khusus yang berasal dari beberapa kepulauan di dunia, salah satunya adalah Ainu yang merupakan penduduk asli masyarakat Jepang, di daerah Pulau Karafuto dan Hokkaido. Ras Khusus tersebut menciptakan negara yang saat ini disebut dengan Negara Matahari Terbit (大日本) dan merupakan sebuah negara dengan perpaduan kehidupan modern dan kebudayaan tradisional yang menjadi daya tarik bagi pihak asing. Banyak orang asing yang datang ke Jepang untuk melakukan kunjungan wisata, studi (belajar di Universitas), perjalanan dinas, dan lain sebagainya. Kegiatan tersebut disambut dengan baik oleh masyarakat Jepang. Tetapi kegiatan yang melibatkan orang asing tidak menjadikan masyarakat Jepang lantas bersikap westernisasi atau mengadaptasi budaya asing. Salah satu sebab masyarakat Jepang menghindari sikap westernisasi atau budaya kebarat-baratan adalah karena masyarakat Jepang memiliki tingkat kewaspadaan (awareness) yang tinggi atas budaya mereka sendiri. Salah satu faktor yang menyebabkan masyarakat Jepang memiliki tingkat awareness yang tinggi oleh karena munculnya kecemasan masyarakat Jepang dalam melakukan komunikasi dengan orang yang tidak dikenal atau disebut pula orang asing. Orang asing yang dimaksud ialah orang yang berasal dari Negara non - Jepang atau bukan warga Negara Jepang dan orang asing yang merupakan Warga Negara Jepang namun belum memiliki komunitas di negara tersebut.

Kecemasan untuk melakukan komunikasi dikenal sebagai communication apprehension . Orang yang aprehensif (prihatin atau takut) di dalam berkomunikasi akan menarik diri dari pergaulan, berusaha sekecil mungkin untuk berkomunikasi, dan akan berbicara jika terdesak 
saja. Bila kemudian ia terpaksa berkomunikasi, sering pembicaraannya tidak relevan, sebab berbicara yang relevan tentu akan mengundang reaksi yang baik dari orang lain. Sebaliknya salah satu faktor pembicaraan yang tidak relevan disebabkan oleh komunikasi yang tidak berlangsung dua arah karena adanya kecemasan.

Sebagaimana diketahui, bahwa masyarakat Jepang sangat menjunjung tinggi harga diri manusia. Oleh karena itu, dalam sebuah pembicaraan, privacy atau pembicaraan yang bersifat rahasia/keadaan sendirian tanpa gangguan (Kamus Besar Bahasa Inggris - Indonesia, 1995:
67) menjadi prioritas bagi masyarakat Jepang. Beberapa peneliti telah menyatakan bahwa "apa yang membuat suatu hal privat adaalh sebagian besarnya merupakan pentingnya hal ini bagi konsepsi kita akan diri kita sendiri dan bagi hubungan kita dengan orang lain" (Schoeman, 1984: 406). Petronio (2000: 71) menyatakan bahwa orang mendefinisikan informasi privat sebagai informasi mengenai hal - hal yang sangat berarti bagi mereka. Oleh karena itu, proses mengomunikasikan informasi privat dalam hubungan dengan orang lain menjadi pembukaan pribadi (private disclosure).

Tabel 3.1.

Tingkat Kecemasan Orang Jepang

Berdasarkan Jumlah Persentase Pada Pria dan Wanita

\begin{tabular}{|l|c|c|}
\hline \multicolumn{1}{|c|}{ Kecemasan Orang Jepang } & Pria & Wanita \\
\hline Kematian (death anxiety) & $54 \%$ & $34 \%$ \\
Bencana alam & $50 \%$ & $38 \%$ \\
Berbicara di depan umum & $45 \%$ & $29 \%$ \\
Masalah pekerjaan & $42 \%$ & $29 \%$ \\
Kesendirian/terisolasi & $34 \%$ & $21 \%$ \\
Rasa frustasi / Ekspresi kemarahan & $34 \%$ & $19 \%$ \\
Masalah teknologi & $34 \%$ & $13 \%$ \\
Hubungan asmara & $27 \%$ & $18 \%$ \\
Tanggung jawab terhadap keluarga & $30 \%$ & $15 \%$ \\
Konflik terhadap Negara lain & $13 \%$ & $7 \%$ \\
Tragedi transportasi publik & $11 \%$ & $8 \%$ \\
Lansia (elderly atau older adults) & $14 \%$ & $4 \%$ \\
\hline
\end{tabular}

Sumber : Bruskin/Goldring Research Report, Februari 1993, hlm. 4 (Berko, Wolvin dan Wolvin 1995:529). 
Penelitian ini bertujuan untuk memberikan pengetahuan tambahan bagi bidang yang belum pernah diteliti ini. Berdasarkan penelitian sebelumnya, para peneliti mengemukakan satu hipotesis dan membuat empat pertanyaan penelitian untuk mencapai tujuan penelitian dalam menyelidiki batasan-batasan privasi di dalam komunikasi masyarakat Jepang pada umumnya. Pertanyaan-pertanyaannya adalah sebagai berikut:

Hipotesis 1: Orang Jepang akan cenderung melakukan komunikasi terbuka/pembukaan pribadi (private disclosure) dengan sesama orang Jepang dibandingkan dengan orang yang berasal dari negara lain.

Pertanyaan Penelitian 1: Apakah orang Jepang dapat melakukan komunikasi terbuka/ pembukaan pribadi (private disclosure) dengan orang yang berasal dari negara lain atau orang yang berasal dari ras yang berbeda?

Pertanyaan Penelitian 2: Apakah orang Jepang yang melakukan komunikasi dengan sesame orang Jepang menggunakan kode etik tertentu sehingga orang yang bukan warga Negara Jepang tidak mengetahui isi pembicaraan orang Jepang tersebut?

Pertanyaan Penelitian 3: Apakah orang Jepang dapat melakukan pernikahan lintas Negara (pernikahan yang melibatkan dua orang yang masing - masing berasal dari Negara yang berbeda)?

Pertanyaan Penelitian 4: Apakah pernikahan tersebut dapat mempengaruhi komunikasi yang terjadi pada pasangan tersebut? (Sebagai contoh, lelaki Jepang menikah dengan dengan wanita Rusia, maka lelaki Jepang akan lebih terbuka dalam berkomunikasi dan wanita Rusia akan memiliki sikap ke-timur-an).

Sampel pada penelitian ini melibatkan sejumlah responden yang merupakan mahasiswa Graduate dan Doctoral dari Universitas yang terletak di Kota Sagamihara, Jepang Graduate University for Advanced Studies. Para mahasiswa beserta dosen dan staf diminta untuk menjawab kuesioner yang meminta mereka untuk melakukan hal-hal ini:

1. Melakukan identifikasi antara komunikasi pembukaan pribadi (private disclosure) dan komunikasi tertutup (exclusive communication).

2. Melakukan komunikasi silang yaitu mahasiswa Jepang menggunakan bahasa asing dan mahasiswa asing menggunakan bahasa Jepang untuk mengetahui kode etik yang tersembunyi dalam bahasa Jepang.

3. Mengukur tingkat kecemasan orang Jepang dengan cara membuka rahasia sesama rekan mahasiswa di hadapan peneliti, mahasiswa asing, dosen dan staf dan memperkirakan perlakuan yang akan diterima setelah rahasia tersebut terungkap.

4. Menjawab pertanyaan jenis-jenis kecemasan yang muncul pada masyarakat Jepang.

5. Memberikan solusi dari pertanyaan nomor 4 .

Peneliti melakukan kode atas jawabanjawaban yang diberikan oleh responden ke dalam tiga kategori utama, yaitu: kecemasan komunikasi, kode etik, dan rahasia. Kemudian data ini dianalisis dengan berbagai macam teori untuk menghasilkan temuan sebagai berikut:

1. Hipotesis 1 diterima, orang Jepang hanya akan melakukan pembukaan diri (private disclosure) terhadap orang Jepang kecuali komunikasi terjadi dalam pernikahan yang melibatkan orang Jepang dengan Warga Negara Asing maka orang Jepang tersebut akan melakukan pembukaan diri (private disclosure) dengan pasangannya dalam pernikahan tersebut.

2. Kecemasan komunikasi pada masyarakat Jepang tidak dipicu oleh satu macam isu, namun meliputi berbagai macam hal yang meliputi keadaan ekonomi, keluarga, status di masyarakat, dan lain sebagainya.

Rumusan masalah yang akan dibahas dalam penelitian ini adalah : (1) Bagaimana 
komunikasi, pembukaan pribadi (private disclosure), dan kecemasan dapat terjadi pada masyarakat Jepang, serta (2) Faktor apa yang memunculkan komunikasi, pembukaan pribadi (private disclosure), dan kecemasan yang terjadi pada masyarakat Jepang.

Peneliti menyimpulkan bahwa penelitian menunjukkan komunikasi, pembukaan pribadi (private disclosure), dan kecemasan pada masyarakat Jepang tidak begitu berbeda dari masyarakat dari Negara lain sebagaimana telah diasumsikan. Selain itu, penelitian ini dapat menggunakan teori baru yaitu Teori Manajemen Privasi Komunikasi yang dicetuskan oleh Sandra Petronio pada tahun 2002. Teori ini secara garis besar menjelaskan tentang pembukaan di dalam hubungan membutuhkan pengelolaan batasan public dan privat. Batasan - batasan ini ada di antara perasaan yang ingin diutarakan oleh seseorang dan perasaan yang ingin disimpan. Pembukaan di dalam perkembangan hubungan lebih dari sekedar mengutarakan informasi privat kepada orang lain. Dibutuhkan negosiasi dan koordinasi akan batasan. Keputusan mengenai pembukaan harus dimonitor secara intensif.

Tinjauan pustaka yang meliputi penelitian ini adalah perbedaan latar belakang budaya, psikokultural, sosiokultural, dan pengaruh lingkungan (Gudykunts dan Kim, 1997: 51). Pada tahap awal, dalam jangka waktu pendek, kecemasan komunikasi pada orang Jepang disebabkan oleh ketakutan atas peristiwaperistiwa yang tidak dapat diprediksi.

\section{Metodologi Penelitian Tipe Penelitian}

Sesuai dengan tujuan penelitian maka tipe penelitian yang digunakan adalah pendekatan kualitatif. Penelitian dilakukan pada sejumlah partisipan untuk mengetahui cara pandang mereka. Penelitian meliputi pengumpulan data secara bertahap, perbaikan, dan penginterkorelasian antar informasi (Strauss \& Corbin, 1990:5). Menggunakan Teori Manajemen Privasi
Komunikasi yang memfokuskan studinya pada aspek - aspek peraturan dan sistem metateori. Dengan adanya dasar metateoretis ini, teori ini membuat tiga asumsi mengenai sifat dasar manusia, yaitu (1) Manusia adalah pembuat keputusan, (2) Manusia adalah pembuat peraturan dan pengikut peraturan, (3) Pilihan dan peraturan manusia didasarkan pada pertimbangan akan orang lain dan juga akan konsep diri.

Penelitian dilaksanakan pada saat peneliti menjadi mahasiswa pertukaran di Okinawa, Jepang pada April 2015. Kemudian pengumpulan dan pengolahan data dilanjutkan hingga bulan Maret 2016. Tempat penelitian dilakukan di kampus Graduate University for Advanced Studies, Sagamihara, Jepang dengan subjek mahasiswa Jepang dan mahasiswa Indonesia yang sedang melakukan studi S2 dan S3 di kampus tersebut.

Berdasarkan data yang diperoleh peneliti melalui nara sumber, jumlah mahasiswa Jepang maupun mahasiswa Indonesia yang sedang melakukan studi/kuliah di Graduate University for Advanced Studies, Sagamihara, Jepang, tidak lebih dari 100 orang. Hal ini tidak dapat dipungkiri karena universitas tersebut merupakan universitas cabang dari universitas induk yang berada di Chiba University. Universitas cabangyang dimaksud ialah universitas tersebut berdiri atas prakarsa dari universitas induk, yang mana mahasiswa di universitas tersebut seluruhnya merupakan mahasiswa Master dan Doktor (S2 dan S3) serta tidak adanya gedung untuk masing-masing jurusan. Sehubungan dengan hal ini, mahasiswa disediakan berbagai macam laboratorium dan diperkenankan untuk menghadiri mata kuliah regional yang diadakan di universitas induk pada waktu tertentu. Selain itu, mahasiswa di universitas tersebut, tersebar dalam berbagai jurusan dan merupakan mahasiswa research yang telah lulus dari Sarjana Strata 1.

Penelitian menggunakan strategi pendekatan studi kasus, yaitu peneliti melakukan ekspolasi suatu program kejadian, aktivitas, proses, satu atau lebih individu. Kasus dibatas pada waktu dan aktivitas tertentu. Peneliti 
kemudian mengumpulkan informasi secara detail menggunakan teknik pengumpulan data pada suatu selang waktu tertentu (Stake, 1995: 6).

Dalam penelitian, subjek penelitian ditentukan dan dibatasi dengan kriteria: mahasiswa, dosen, maupun staf Graduate University for Advanced Studies yang intensif berinteraksi dengan mahasiswa research yang berasal dari luar Jepang, umumnya berasal dari Negara Asia Pasifik, menggunakan beasiswa sebagai mahasiswa di kampus tersebut dan sudah melakukan studi minimal dua tahun. Dalam penelitian ini, peneliti melakukan identifikasi budaya sebagai penyebab kecemasan dan tingkat intensitas komunikasi yang dilakukan mahasiswa Jepang dengan mahasiswa non - Jepang.

Beberapa partisipan yang sesuai dengan kriteria penelitian, telah dikumpulkan dan diwawancarai oleh peneliti. Berikut subjek penelitian dari Graduate University for Advance Studies:

1. Chikama Momoko (ちかま桃子), merupakan mahasiswi Jepang tahun kedua dengan jurusan Aerospace Engineering di universitas tersebut.

2. Arashiro Naoki (新城直木先生), merupakan dosen sekaligus asisten Professor untuk mahasiswa research yang telah mengajar selama lima tahun.

3. Tsu-Ting, Ran (津陳具ラン), merupakan mahasiswi dari Taiwan tahun kedua sebagai mahasiswi S2 dengan jurusan Sastra Jepang.

4. Mo, Shu-Han (モシュウハン), merupakan mahasiswi dari RRC jurusan Sastra Jepang tahun kedua dan bekerja sebagai part-timer.

5. Souvannathongkham (ミー), merupakan mahasiswa dari Laos tahun ketiga sebagai mahasiswa S3 dengan jurusan Aerospace Engineering.

6. Daphne Mahusay Sy (ダフネー) merupakan mahasiswi dari Filipina tahun ketiga dengan jurusan Ilmu Komunikasi dan Sastra
Jepang dan bekerja part-time.

7. Seiko Tomari (途万理聖子 先生), merupakan Professor sekaligus staf International Research Student yang telah bekerja selama sepuluh tahun.

8. Ario Birmiawan Widyoutomo (Ario, dalam lafal kanji akan ditulis 000), merupakan mahasiswa dari Indonesia tahun ketiga jurusan Aerospace Engineering.

9. Sari, merupakan mahasiswa dari Indonesia mahasiswa tahun ketiga jurusan Aerospace Engineering.

Setiap subjek penelitian memiliki peran masing-masing yang bertugas untuk memberikan informasi sebagai nara sumber yang terpercaya kepada peneliti dan digunakan untuk keabsahan data penelitian. Dalam pengumpulan data, peneliti menggunakan metode wawancara, observasi, dan kuesioner. Wawancara adalah pengumpulan data secara tanya jawab secara langsung ataupun melalui media lain seperti email atau telephone. Observasi adalah metode pengamatan atas bentuk interaksi, kedekatan, penggunaan bahasa verbal, dan non - verbal pada komunikasi antara subjek pelaku dan nara sumber. Peneliti melakukan observasi partisipan dengan ikut sereta dalam interaksi, bergabung dalam peristiwa - peristiwa penelitian dan menjadi bagian kelompok penelitian. Kuesioner adalah suatu teknik pengumpulan informasi yang memungkinkan analis mempelajari sikap-sikap, keyakinan, perilaku, dan karakteristik beberapa orang utama di dalam organisasi yang bisa terpengaruh oleh sistem yang diajukan atau oleh sistem yang sudah ada.

Teori yang digunakan dalam penelitian ini adalah Teori Manajemen Privasi Komunikasi berdasarkan penelitian Sandra Petronio. Teori Manajemen Privasi Komunikasi berbeda dengan kebanyakan teori yang ada karena teori ini sangat baru. Ide - ide dalam Teori Manajemen Privasi Komunikasi (CPM) sebenarnya telah berusia lebih dari dua puluh tahun (Petronio, 1991), tetapi 
pernyataan formal pertama mengenai versi matang dari teori ini tidak muncul hingga saat Petronio menerbitkan buku yang berjudul Boundaries of Privacy pada tahun 2002.

Munculnya teori baru ini menarik karena adanya tiga alasan. Yang pertama, teori ini menarik karena hal ini menunjukkan pemikiran yang terkini dalam disiplin ilmu komunikasi. Hal ini mengindikasikan bahwa pemikiran yang segar dan baruterus memberikan penerangan bagi pertanyaan - pertanyaan mengenai perilaku komunikasi. Munculnya teori baru memberikan gambaran akan hidupnya komunikasi sebagai bidang ilmu.

Yang kedua, dan masih berkaitan dengan antusiasme yang muncul akibat keterkinian teori ini, adalah fakta bahwa CPM bertumbuh secara khusus dari fokus terhadap komunikasi. Hal ini menjadi bukti akan kematangan dan pertumbuhan bidang ilmu komunikasi. Beberapa teori lain, bermula dari disiplin ilmu lain. Misalnya, Teori Interaksi Simbolik, berasal dari sosiologi. Para peneliti komunikasi sangat menghargai SI karena teori ini sangat menekankan pentingnya interaksi dalam membentuk rasa diri (sense of self). Teori Disonansi Kognitif berawal dari bidang ilmu psikologi, tetapi para peneliti komunikasi melihat bahwa teori ini berguna karena pemikiran pemikiran yang memperjelas praktik persuasi. Para peneliti komunikasi telah menemukan teori - teori ini dan yang lainnya sangat berguna untuk membingkai penelitian mengenai perilaku komunikasi. Walaupun begitu, akan sangat menolong apabila terdapat teori yang menempatkan konsep komunikasi sebagai pusat di dalam proses penjelasan. Teori CPM melakukan tepat seperti demikian, memungkinkan para peneliti untuk lebih fokus dalam penelitian mengenai proses komunikasi dan praktik praktik komunikasi khusus.

Teori Manajemen Privasi Komunikasi berakar pada asumsi - asumsi mengenai bagaimana seorang individu berpikir dan berkomunikasi sekaligus asumsi-asumsimengenai sifat dasar manusia. Petronio (2002) melihat bahwa manusia membuat pilihan dan peraturan mengenai apa yang harus dikatakan dan apa yang harus disimpan dari orang lain berdasarkan "kalkulus mental" yang didasarkan pada kriteria penting, beberapa di antaranya seperti budaya, gender, konteks. Ia berargumen bahwa kriteria - kriteria ini mencakup pertimbangan akan orang lain yang terlibat dan juga akan konsep diri. Untuk alasan ini, Petronio menggunakan istilah pembukaan (disclosure) dan pembukaan pribadi (private disclosure) daripada menggunakan istilah pembukaan diri (self-disclosure) dalam CPM.

\section{Skema Penelitian Penelitian}

Chikama Momoko bertemu dengan berbagai macam orang dalam kehidupannya dosen dan asisten dosen, rekan sekerja, teman sekelas, mahasiswa senior, teman satu asrama, dan seterusnya - ia terlibat dalam negosiasi kompleks antara privasi dan keterbukaan. Skema penelitian akan membahas teori Manajemen Privasi Komunikasi (Communication Privacy Management-CPM), yang membantu pembaca untuk memilah dan menjelaskan kompleksitas proses ini. Sandra Petronio $(2002,252)$ menyatakan bahwa CPM adalah teori praktis yang didesain untuk menjelaskan isu-isu "keseharian" seperti yang digambarkan dalam kegiatan - kegiatan Chikama Momoko. Sebagaimana diamati oleh Petronio, pertanyaan apakah mengatakan sesuatu yang Anda pikirkan kepada seseorang adalah hal yang rumit, tetapi hal ini sering kali Anda hadapi dalam kehidupan sehari-hari.

Sebagai contoh, kegiatan Chikama Momoko yang dilakukan pada hari senin. Ia harus masuk ke kelas pada pukul 8.20 pagi. Pada saat itu, Ia melihat teman-teman sekelasnya berkumpul untuk mendapatkan pengarahan dari Professor dan asisten Profesor mengenai tugas terbarunya. Ia sangat khawatir saat terpilih sebagai ketua project untuk tugas tersebut. Ia pun memohon kepada mahasiswa senior agar membantunya mengerjakan 
tugas tersebut betapapun sulitnya. Kemudian, setelah mata kuliah tersebut berakhir, Ia bergegas untuk melakukan kerja part - time pada sore hari dan bertemu kedua temannya, Mo-Shu Han dan Daphne. Ia mengira akan melakukan kesalahan di tempat kerja namun hal tersebut tidak terbukti. Seusai bekerja part-time,ia pun kembali ke kampus untuk mengerjakan tugas bersama temantemannya. Mahasiswa senior dari Laos berhasil membantunya dalam mengatasi kecemasan dan meminta Chikama Momoko untuk lebih terbuka dalam berkomunikasi. Kemudian dalam perjalanan pulang ke asrama, Chikama Momoko berjalan bersama Tsu - Ting, Ran yang juga tinggal di asrama.

Ketika mengamati keseharian Chikama Momoko, maka dapat disimpulkan pertanyaan mengenai pembukaan, (1) Ia menceritakan cemas akan tugas yang diberikan padanya kepada teman-temannya, (2) Ia khawatir akan melakukan kesalahan saat di tempat kerja, (3) Ia kembali ke kampus untuk mengerjakan tugas bersama mahasiswa senior namun hal tersebut menjadi menyenangkan karena dukungan yang diberikan oleh Souvanathongkham, (4) Ia bertemu dengan teman satu asrama namun ia tidak yakin apakah harus menceritakan runtutan kejadian yang ia lakukan pada hari itu atau tidak.

\section{PEMBAHASAN}

Semua contoh ini memberikan gambaran mengenai pernyataan Petronio bahwa memutuskan apa yang akan diungkapkan dan apa yang harus dirahasiakan bukanlah keputusan yang dapat langsung diambil, melainkan merupaakn tindakan penyeimbangan yang berlangsung secara terus menerus. Baik keterbukaan dan privasi memiliki resiko serta penghargaan bagi Chikama Momoko dalam semua situasi yang dihadapinya.

Lebih jauh lagi, Chikama Momoko harus berpikir mengenai resiko dan penghargaan yang dihasilkan oleh keputusan yang Ia buat bagi orang-orang dengan siapa Ia berinteraksi. Bagaimana perasaan Professor, asisten Professor, serta mahasiswa senior apabila ia menolak untuk menjadi ketua project dalam tugas yang diberikan kepadanya? Selain itu, apakah ia harus menceritakan kepada Tsu - Ting, Ran mengenai perasaaannya terhadap Souvanathongkham? Apakah yang akan terjadi bila Tsu - Ting, Ran mengatakan hal tersebut? Mungkin akan terjadi $\mathrm{CoC}$ yang berakibat sikap canggungg di dalam kelas. Semua permasalahan ini, relasional maupun individual, menciptakan proses keseimbangan yang kompleks yang disebut Petronio sebagai Teori Manajemen Privasi Komunikasi.

Asumsi-asumsi ini, secara keseluruhan, mewakili sebuah persepsi aktifmengenai manusia dan merupakan sebuah penggambaran akan manusia yang terlibat di dalam hidup berhubungan sampai pada batas di mana diri dan orang lain saling terkait (Tabel 4.1). Ide akan adanya keterkaitan ini sangat penting bagi CPM. Diri sendiri dan orang lain tidak hanya terlibat di dalam hubungan, tetapi pembukaan juga terkait dengan konsep privasi. Sebagaimana diamati oleh Petronio dan Caughlin (2006), privasi hanya dipahami dalam ketegangan dialektis dengan pembukaan. Jika kita membuka semuanya, kita tidak akan memiliki konsep privasi. Sebaliknya, jika semua informasi bersifat pribadi, ide mengenai pembukaan tidak akan masuk akal. Hanya dengan memasangkan keduanya maka kedua konsep ini dapat didefinisikan. 
Tabel 4.1. Asumsi CPM

\begin{tabular}{|l|l|}
\hline TEORI CPM & SEMUA TEORI DIALEKTIKA \\
\hline Pilihan manusia & Hidup berhubungan yang diatur oleh perubahan \\
\hline Aturan yang dibuat oleh manusia & $\begin{array}{l}\text { Kontradiksi sebagai fakta fundamental dalam } \\
\text { hidup berhubungan }\end{array}$ \\
\hline Pertimbangan sosial & \\
\hline
\end{tabular}

\section{PENUTUP}

\section{Simpulan}

Komunikasi masyarakat Jepang memiliki persamaan dengan komunikasi Warga Negara Asing lainnya. Bagi seorang warga Negara asing yang datang ke Jepang tentu ingin bercakapcakap dengan orang Jepang secara leluasa. Namun hal tersebut tidak dapat dilakukan secara instan atau terjadi begitu saja. Perlu proses dalam jangka waktu lama sehingga hal tersebut dapat terwujud dan terjalin dengan baik.

Kecemasan yang dialami masyarakat Jepang pada umumnya, juga dapat mempengaruhi gaya berkomunikasi masyarakat tersebut terhadap warga Negara asing. Hal ini tidak dapat dipungkiri dapat menjadi penghambat bagi keberlangsungan jalinan komunikasi yang diinginkan oleh warga Negara asing terhadap masyarakat Jepang. Sementara masyarakat Jepang memiliki tendensi untuk melakukan komunikasi secara internal dengan sesame warga Jepang, sebaliknya warga Negara asing memiliki tendensi untuk melakukan percakapan dengan pembukaan pribadi (private disclosure).

Sebagai contoh, yang terjadi antara mahasiswa Indonesia dengan sesama mahasiswa Indonesia pada skema penelitian. Dapat disimpulkan bahwa komunikasi yang terjalin antara kedua mahasiswa tersebut berjalan dengan baik bahkan muncul intensitas komunikasi yang menciptakan hubungan. Tingkat intensitas tersebut bersama dengan kepercayaan akan menimbulkan suatu in-relationship antara kedua mahasiswa tersebut yang apabila diterapkan pada masyarakat Jepang, akan membutuhkan proses yang lama.

Oleh karena itu, sangat disarankan kepada warga Negara asing yang akan berkunjung ke Jepang untuk melakukan survey terlebih dahulu. Mengenai tempat tinggal, transportasi, hingga budaya. Alangkah lebih baik lagi, apabila warga Negara asing, dalam hal ini warga Negara Indonesia yang akan berkunjung ke Jepang, untuk tujuan wisata, studi, perjalanan dinas, dan lain sebagainya-mempelajari terlebih dahulu bahasa Jepang serta etiket (etiquette) dari budaya setempat. Sehingga tidak terjadi salah paham maupun mis - komunikasi dalam berperilaku dengan masyarakat Jepang.

Universitas Diponegoro, sebagai institusi yang mengirimkan mahasiswa maupun mahasiswi untuk Program Pertukaran ke Jepang, membekali kandidatnya agar selalu mawas diri dan siap akan segala tantangan yang ada. Program pertukaran tersebut selalu diadakan dua kali dalam satu tahun dan terbuka bagi mahasiswa undergraduate (S1) maupun graduate (S2). Mahasiswa yang sedang dalam proses pengerjaan tugas akhir, disarankan untuk tetap melaksanakan tugas tersebut pada saat berlangsungnya program. Masyarakat Jepang pada umumnya, beserta civitas akademika 
pada khususnya, akan senang hati membantu mahasiswa pertukaran yang sedang melakukan tugas akhir di kampus tempat ia berasal.

Namun, penelti tidak lupa mengingatkan agar mahasiswa/mahasiswi untuk tetap mengikuti kegiatan belajar mengajar yang diselenggarakan institusi di Jepang, agar setiap project yang diberikan Professor maupun asisten Professor kepada mahasiswa dapat diselesaikan dengan baik sekaligus berguna untuk pembuktian bahwa Warga Negara asing, khususnya pelajar dari In- donesia memiliki daya saing yang tidak kalah baik dengan Warga Negara lain.

Akhir kata, peneliti ingin mengucapkan terima kasih kepada semua pihak atas terwujudnya penelitian ini. Semoga penelitian ini dapat bermanfaat bagi Institusi, mahasiswa/ mahasiswi, individu yang lebih ingin mengenal kebudayaan dan masyarakat Jepang pada umumnya serta civitas akademika pada khususnya. 


\section{DAFTAR PUSTAKA}

West, Richard dan Turner, Lynn H. (2008). Pengantar Teori Komunikasi, Analisis dan Aplikasi. Jakarta : Salemba Humanika.

Prasetyo, Bambang dan Jannah, Lina M. (2013). Metode Penelitian Kualitatif, Teori dan Aplikasi. Jakarta : PT. RajaGrafindo Persada.

Pramesti, Getut. (2014). Kupas Tuntas Data Penelitian dengan SPSS 22. Jakarta : PT. Elex Media Komputindo.

Ogawa, Iwao. (2000). Minna No Nihon-Go I. Japan : 3A Corporation.

Ogawa, Iwao. (2001). Minna No Nihon-Go II. Japan : 3A Corporation.

Aiko, F.S. (2016). “Dai Nippon: Enlarge the Society of Japanese People and Culture,” Tokyo Notice Board 82: p. $16-22$. 